\section{Greek politics}

\section{Cultured science}

The success of the new socialist government in Greece under Mr Andreas Papandreou seemed to have introduced a touch of rare glamour to science politics: the actress Melina Mercouri was to have been Minister for Culture and Science. Unfortunately the "science"' in her title is merely a tag, and Miss Mercouri's role will be more to do with monuments than molecular biology.

Affairs more directly affecting scientists are likely to rest with the Minister of Economic Coordination (Mr Apostolos Lazaris) and the Minister of Education and Religious Affairs (Mr Leftheris Verivakis). Lazaris will master the three-year-old Science, Research and Technology Agency, which is reorganizing basic science funding along the usual western lines of a research council; and Verivakis will direct the reform of the 14 university-level institutions of Greece.

If its election campaign promises are to be believed the new government will show less interest than the previous one in a (hypothetical) Greek nuclear power programme. Recent earthquakes have increased popular resistance to nuclear energy (for fear of damage to reactors), and Papandreou has called for "more research".

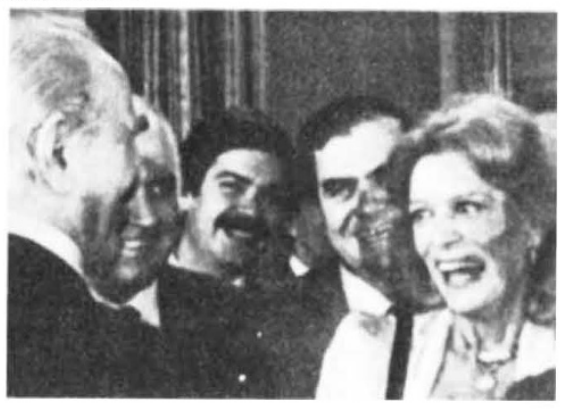

President Caramanlis meets Minister Mercouri

Papandreou, for 20 years a professor of economics at Harvard University, is also interested in university reform, and is likely to encourage Verivakis (a 40-year-old lawyer) to move rapidly to implement his party's proposals. These broadly follow the lines of the reform committee, headed by Professor F. Mitsis, which reported to the last government. Verivakis, though, may go further in proposing open entry to the universities and the abandonment of the present entrance examination.

Verivakis may also attempt to increase the numbers of postgraduate students in Greece - something that should follow the substitution of the paternalistic "chair" system by a more modern departmental organization for the universities.

Opening the universities to all comers, however, may have to wait until the Greek economy picks up. For example, in the 1982 entrance examinations, just finished, there were 82,240 candidates for 26,694 places.

Robert Walgate

\title{
Scientists against nuclear weapons - a list
}

Readers - particularly those who do not realize that 24-31 October is United Nations Nuclear Disarmament Week - may be interested to know of the following organizations which have been set up by and for scientists who are opposed to nuclear armaments. The self-expressed objectives of the organizations are generally speaking, to coordinate and enhance technically informed opinion, inside and outside government, concerning nuclear armaments policies. The expanding membership of these organizations reflects a growth of concern in the scientific community, illustrated also by a statement signed by at least half of those attending the recent International School of Plasma Physics at Varenna (though not by the Soviet or Chinese participants). The statement emphasizes that "physicists bear a heavy burden of responsibility for the present danger", and that they should "oppose the resignation and passivity which is so widespread". The following list is not exhaustive and we would like to be informed of other organizations around the world formed for the same purpose.

- Union of Concerned Scientists, 1384 Massachusetts Avenue, Cambridge, Massachusetts 02238, USA.

- Ground Zero, 806 15th Street, Suite 421, Washington, DC 20005, USA.

- Physicians for Social Responsibility, 25 Main Street, PO Box 144, Watertown, Massachusetts 02172, USA.

- International Physicians for Prevention of Nuclear War, 635 Huntingdon Avenue, Boston, Massachusetts 02115, USA.

- Science for Peace, c/o Professor D. Paul, Department of Physics, University of Toronto, Toronto M5S 1A7, Ontario, Canada.
- Canadian Peace Research Institute, Gryffin Lodge, Huntsville POA 1KO, Ontario, Canada.

- Scientists Against Nuclear Arms, 11 Chapel Street, Woburn Sands, Milton Keynes MK17 8PG, UK.

- Medical Campaign Against Nuclear Weapons, 120 Edith Road, London W14, UK.

- The Pugwash Conference on Science and World Affairs is not a "membership organization" in that people attend the annual conference by invitation. Individuals may, however, join the national branches of the organization to be directly informed of its activity.

Philip Campbell
US telecommunications End to AT\&T saga?

\section{Washington}

In a move which could persuade the Reagan Administration to drop anti-trust charges against the massive American Telephone and Telegraph Company (AT\&T, otherwise known as the Bell System), the US Senate has passed legislation that would allow the company to set up a wholly-owned subsidiary to enter the computer and information processing fields.

Similar legislation is expected to be passed soon by the House of Representatives, and a deregulation bill is likely to be signed into law by President Reagan early next year. The bill marks an attempt to bring US telecommunications into line with the technology of the 1980s and is the first major change in structure of federal controls since the 1934 Communications Act.

Congress has been struggling for six years over what to do about AT\&T. Under a consent decree reached with the Department of Justice in 1956, AT\&T the largest company in the world, with assets exceeding $\$ 125,000$ million - was granted a virtual monopoly in the regulated local and long-term telephone markets, but on condition that it did not enter any unregulated markets.
The latter category includes computer equipment and data processing. As these fields have blossomed in recent years, so has AT\&T's desire to enter and compete in them - and therefore to change the terms of the consent decree. This it would now be able to do under the legislation approved by the Senate, through a subsidiary generally known as Baby Bell.

Responding to criticisms that, if the new company and its parent were too closely linked, its degree of support would constitute unfair competition against other companies already in the information processing field, the Senate has stipulated that the two should have an "arms-length" relationship. This is one of the conditions that the Justice Department has decreed must be included in any deregulation legislation, if it is to drop its anti-trust suit against the company. That suit, begun six months ago, remains adjourned.

More concessions are expected to be demanded in the House, reflecting the views of AT\&T's largest corporate subscribers. Many are alarmed, for example, that Baby Bell might establish its own more sophisticated long-distance telecommunications system to compete with the now ageing Bell System, but without the local controls to which the current Bell System, which carries 98 per cent of all long-distance voice and data transmission, is subject.

David Dickson 